\title{
The Financial and Operating Performance of China's Newly Listed H-firms
}

Samuel G. H. Huang and Frank M. Song

School of Economics and Finance

Faculty of Business and Economics

The University of Hong Kong, Pokfulam Road, Hong Kong

We thank Chong-en Bai, William Megginson, Alice Shiu, Wing Suen, Jack Zhang, and participants in the International Workshop on the Chinese Economy in Shanghai and in the CEANA 2002 annual meeting in Atlanta for helpful comments. Samuel Huang acknowledges the financial support of an HKU-PRC Swire doctoral scholarship.

Huang's email: huangg@hkusua.hku.hk Tel: (852) 2857-8637, Fax: (852) 2548-1152.

Song’s email: fmsong@econ.hku.hk Tel: (852) 2857-8507, Fax: (852) 2548-1152. 


\title{
The Financial and Operating Performance of China's Newly Listed H-firms
}

\begin{abstract}
This study compares, with the use of accounting data, the pre- and postlisting financial and operating performance for the complete sample of the $\mathrm{H}$-firms that were incorporated in mainland China and listed in Hong Kong. Theoretically, there are two major opposing influences on the performance change of these newly listed firms: the negative IPO effect and the positive privatization effect. Our major findings are: (1) the IPO effect dominates the privatization effect, so that the $\mathrm{H}$-firms experienced a significant decrease in profitability and operating efficiency after listing, and (2) the performance of a control sample of newly listed private firms declined more than that of the $\mathrm{H}$-firms, probably because the positive privatization effect somewhat offset the negative IPO effect for the H-firms. This paper is the first to document the positive effect of revenue privatization in listed Chinese companies.
\end{abstract}

JEL Classification: G34 G38

Keywords: Company performance, share issue privatization (SIP), state-owned enterprises (SOEs), IPO, China, reform, Hong Kong capital market 


\section{The Financial and Operating Performance of China's Newly Listed H-firms}

\section{Introduction}

China has been increasingly listing its state-owned enterprises (SOEs) since 1990, both in domestic stock markets (Shanghai and Shenzhen exchanges) and abroad (Hong Kong, New York, London, and Singapore exchanges). Currently, Chinese SOEs have issued four types of public shares: A-shares, B-shares, H-shares, and Red Chips. A-shares are listed on the Shanghai or Shenzhen Exchange in mainland China, denominated in RMB and restricted to domestic investors. B-shares are also listed in mainland China, but denominated in US dollars (Shanghai-listed companies) or Hong Kong dollars (Shenzhen-listed companies), and were restricted to foreign investors until early 2001. H-shares are listed in Hong Kong, New York, London, or Singapore and restricted to foreign investors. In contrast with A-, B-, or H-shares, whose companies are incorporated in mainland China, Red Chips companies are incorporated and listed in Hong Kong and are controlled (at least 35\%) by state-owned organizations or by provincial or municipal authorities in mainland China.

As of December 2000, there are 1088 companies with A-shares, 114 with B-shares, 52 with H-shares, and around 60 with Red Chips. Among them, 86 companies have A- and B-shares simultaneously, and 19 companies have A- and $\mathrm{H}$-shares simultaneously. $\mathrm{H}$-shares are mostly listed in Hong Kong. Among the $52 \mathrm{H}$-shares, only one is exclusively listed in New York, and only one exclusively listed in Singapore; all the others are either exclusively listed in Hong Kong or jointly listed in Hong Kong and in either New York or London.

In recent years, there have been empirical studies on Chinese listed companies, such as $\mathrm{Xu}$ and Wang (1999) and Chen, Firth, and Kim (2000). To our knowledge, this paper is the first effort to study the impact of listing on the performance of the firms with H-shares (we refer to them as the H-firms). Almost simultaneously, Wang, $\mathrm{Xu}$, and $\mathrm{Zhu}$ (2001) investigated the impact of 
listing of firms with A-shares (A-firms). Like us, they document that company performance decreased significantly after listing, but they could not determine whether the privatization effect in these Chinese companies is positive or negative. This paper is the first to show that the privatization effect in China's newly listed companies may still be positive as in other countries. It does so by introducing a control set of private newly listed companies.

On the company performance change of these newly listed $\mathrm{H}$-firms, there are two strands of related literature, on share issue privatizations (SIPs) and on IPOs of the previously privately held companies. Some papers suggest that company performance should improve, while others suggest that it should deteriorate.

\subsection{Literature on Privatization Effect}

Papers on SIPs generally suggest that company performance should improve. By SIPs, we mean that some or all of the government's stake in SOEs is sold to private investors through public share offerings or SOEs become mixed firms by introducing private investors via IPOs ${ }^{1}$. Generally, we call privatization control privatization when governments surrender voting control rights after privatization, and revenue privatization when governments sell a minority ownership stake and do not surrender voting control (Megginson, Nash, and Van Randenborgh (1994, MNR), Boubakri and Cosset $(1998, \mathrm{BC}))$. SIPs have been adopted by the governments as the major and popular way to reform SOEs around the world (Jones et al., 1999).

There seems to be a consensus in the recent literature that SIPs do improve company performance. Megginson and Netter (2001) survey 38 studies that employ accounting and/or real output data to examine the impact of privatization on the operating efficiency and/or financial performance of former SOEs in developed, developing, and transition economies. They find that almost all the papers report an increase in performance associated with privatization. Among 
others, three influential papers (MNR, BC, and D'Souza and Megginson (1999, DM)) use the same methodology and the same proxies to compare pre- with postprivatization performance for SIPs. This methodology was first employed by MNR, and is now referred to as MNR methodology. These three papers document consistent findings: privatization brings significant increases in profitability, output, operating efficiency, and dividend payments, and significant decreases in leverage ratios. These researches are quite representative in that they use a total of 204 companies from 41 countries, including both developed and developing countries; both control privatization and revenue privatization; and both nontransition and transition economies.

As we will show later, all the $\mathrm{H}$-firms are due to revenue privatization. We want to know whether revenue privatization through SIPs can improve company performance. Although no indisputable conclusion has been reached, a positive answer seems to be favored by published studies. On the one hand, in their pioneering paper, MNR find that both full and partial privatization improve the performance of the privatized firms. However, it is more relevant to compare the effects of control versus revenue privatization. BC and DM find that both control and revenue privatizations lead to a significant improvement in operating performance.

D'Souza, Megginson, and Nash (2000) put forward several potential causes of performance improvements in privatized firms: capital market discipline, changes in owners' incentives, changes in CEO and in board of directors, and exposure to competition. Once SIPs have introduced private shareholders, even the still state-controlled listed firms have to give shareholders' wealth maximization high priority under the market pressure from private investors and financial analysts. In addition, they have to disclose their financial statement regularly, and the knowledge of their listing status abroad amounts to a kind of intangible assets. These effects may be among the reasons that even revenue privatizations can improve SOEs' performance.

\footnotetext{
${ }^{1}$ Megginson and Netter (2001) limit the definition of SIPs to the first part of our definition. However, in the study of performance change of SIP firms, the samples that MNR, BC, and DM employ include both secondary offerings and primary offerings of SIPs.
} 


\subsection{Literature on IPO effect}

Researches on IPOs generally suggest that company performance deteriorates after going public. Recent literature has documented that the accounting performance of the newly listed companies in the private sector becomes worse after going public. Jain and Kini (1994), Mikkelson, Partch, and Shah (1997), and Pagano, Panetta, and Zingales (1998) have shown that the performance of newly listed firms declines after IPOs in the private sector (in the US and Italy) and the impact of going public generally fades away within a few years. In the perspective of stock price performance, Ritter (1991), Loughran, Ritter, and Rydqvist (1994), and Laughran and Ritter (1995) find that both initial public offerings and seasoned equity offerings significantly underperform relative to nonissuing firms for five years after the offerings.

Three potential causes are generally put forward. The first is principal-agent problems (Jensen and Meckling (1976)). The agency cost increases as the conflict between the managers and the shareholders becomes worse because the entrepreneurs' ownership declines and the ownership becomes disperse after IPOs. The second is due to earning management. The initial offering companies may overstate their profitability before listing (Teoh et al., 1998). Third, the entrepreneurs may time the offerings of their companies. They tend to list their firms when the companies are showing unusually good performance or could enjoy a favorable market valuation (Pagano, Panetta, and Zingales, 1998). Although there are some benefits of listing-including the gaining of access to a source of finance alternative to banks, enhanced public profile and reputation, and, for Chinese enterprises, access to international funds - the overall effect of IPOs on company performance is negative.

The newly listed $\mathrm{H}$-firms suffer from all the three problems, especially the agency cost. Before an SOE becomes a public company, the state is naturally the largest or even $100 \%$ owner. Related ministries, the state council, or the local government effectively monitors its operation and management, especially in cost control. For example, changes in employees' salaries are 
subject to prior approval consistent with the incentive contracts. Nor can new employees' houses be built without approval in advance from related authorities.

However, after the SOE becomes a public company, especially one listed in Hong Kong, Chinese authorities may be reluctant to monitor the management even though the state's majority shareholder status is unchanged. Economically, the state has less incentive to monitor the listed SOEs, as its share percentage and thus its cash flow right has decreased. Politically, as Hong Kong was a British colony before July 1,1997 and is now a Special Administrative Region of China (HKSAR) on the principle of "One Country Two Systems", HKSAR enjoys a high degree of autonomy. The Chinese government feels the H-shareholders' rights should be honored. However, individual H- or A-firm public shareholders (if any) have neither sufficient incentive nor power to monitor the management. If the market pressure from public shareholders cannot offset the decline of the monitoring from the largest shareholder, the conflict of interest between the manager and the shareholders may be expected to become worse. As a result, the managers may abuse their rights, and the agency problem is likely to become worse.

Moreover, anecdotal evidence suggests that Chinese government may try to solve its other SOEs' problems by merging the unhealthy SOEs with the revenue-privatized firms, and so the merger value is likely to be negative for the listed firms. The government, however, can benefit from such mergers because it does not have to bear all the burden of the unhealthy SOEs, as its cash flow right is much lower than $100 \%$ after introducing private shareholders.

We also have casual evidence on the timing of the H-firms' listing. In 1997, before the Asia Crisis, when the market was booming and the H-firms enjoyed a favorable valuation, $16 \mathrm{H}-$ firms got listed within the year, whereas in 1998, with a bear market, only one H-firm went public in the whole year. Finally we cannot exclude that the H-firms window-dress or misrepresent their financial status in the IPO prospectus. 
As privatization effect and IPO effect are a pair of opposing forces on company performance, we do not have clear idea from theory whether the H-firms' performance should improve or deteriorate after listing. This paper seeks to empirically study the impact of listing of SOEs by employing a complete sample of newly listed H-firms. As a country-specific sample is employed, we try to control the effect of the business cycle and technological change by introducing calendar-year-specific fixed effects into our panel data analysis. Also, we test which effect (the external effect or the privatization and IPO effect) dominates the performance change. Furthermore, we introduce a set of control firms, which were listed around the same period as the $\mathrm{H}$-firms and many of which have similar businesses in China to those of the $\mathrm{H}$-firms, to test whether there is any difference in the impact of listing between the H-firms and the control firms. We find that (1) the negative IPO effect dominates the positive privatization effect, so that the performance of the $\mathrm{H}$-firms became worse after listing, and (2) the performance deterioration of the $\mathrm{H}$-firms is less than that of the control firms. We argue that the privatization effect in China is still positive and the positive privatization effect somewhat offsets the negative IPO effect.

The remainder of this paper is organized as follows. Section 2 describes data and methodology, and in section 3, we present and discuss our results. Section 4 presents some robustness checks, and section 5 concludes this paper.

\section{Data and Methodology}

\subsection{Data}

Our sample covers all the H-firms listed in Hong Kong that have at least two-year annual accounting data after listing. As of December 2000, $50 \mathrm{H}$-firms are listed on the Hong Kong Exchange. However, the term of the postprivatization data for the companies listed after 1998 is too short for our analysis, so this research will employ the 38 of the SOEs that were listed before 1998 and have comparable performance data before and after listing. Also, we construct a 
special control sample by industry, business on the mainland, and time of listing in Hong Kong as follows. Many other listed companies in Hong Kong, especially industrial companies, do business in mainland China. During the period 1993 to 1998, in which our H-firms went public, altogether around 312 companies went public. After deleting the H-firms, Red Chips, and financial companies, there are around 210 companies left. We randomly chose 38 firms from among them to set up a control sample. The industries the control firms and the H-firms engage in are similar: most of them are industrial or real estate firms ${ }^{2}$. We obtained pre- and postprivatization annual accounting data from PACAP and DATASTREAM, supplemented by the firm's placement and offering prospectus and the annual reports. The basic facts on the $\mathrm{H}$-firms and the control firms are given in Table $1^{3}$.

\section{Insert Table 1 Here}

Compared with SIPs in other countries or with previously privately held companies, the Hfirms have several special characteristics as follows.

First, the SIPs of the H-firms are revenue rather than control privatization ${ }^{4}$. In the sample of the $38 \mathrm{H}$-firms, the state or government has more than $50 \%$ ownership in 34 companies and more than $40 \%$ ownership in the other four companies. Furthermore, these four companies also have A-shares, and the markets for A-shares and $\mathrm{H}$-shares are strictly segmented. Investors in Ashares are barred from holding $\mathrm{H}$-shares, and vice versa. Thus, no individual or institution other than the state has a chance to become the largest shareholder in any of these four companies. This characteristic is consistent with the observation of Bourakri and Cosset (1998). As they find, SIPs in developing countries are different from those in developed countries, in which most SIPs are

\footnotetext{
${ }^{2}$ We note that the newly listed private firms and control firms as well are generally smaller than the H-firms. The difference of the performance change may be due not only to the IPO and privatization effect, but also to the size difference.

${ }^{3}$ A detailed description of $\mathrm{H}$-firms, including issue date, size, and state ownership before and after going public, is available upon request. Much of it is also available on websites, such as www.hsi.com.hk and www.e-finet.com.
} 
control privatization, while many of SIPs in developing countries are revenue privatization.

The implication of corporate governance (Shleifer and Vishny, 1997) for firms whose controlling shareholder is the state is different from that for firms whose controlling shareholders are private institutions or families. When the state is the controlling shareholder, the executive directors themselves in the H-firms are not majority or controlling shareholders; they are only representatives (agents) of the Chinese government. No directors hold a significant percentage of shares in the companies that they manage ${ }^{5}$. As a result, both the chairpersons of the board of directors and chief executive officers (CEOs) are only representatives of the state. In most cases, the chairpersons of $\mathrm{H}$-firms have no right to kick out badly performing CEOs. When the controlling shareholders are families, the ultimate beneficiary of corporate governance improvement is private. This is the major difference between the public companies in the private sector and the H-firms. If some combination of involvement by controlling shareholder and sound legal protection for small investors is essential for sound corporate governance (La Porta et al., 2000; Shleifer and Vishny, 1997), merely going public does not guarantee improved performance.

Second, the public offerings of the H-firms are mainly primary rather than secondary offerings. Jones et al. (1999) find that nearly all SIPs in developed countries are essentially secondary offerings, in which only the governments sell their shares and no money flows to the firms themselves. In contrast, almost all the listed SOEs in Hong Kong were primary offerings that brought capital flows into the firms instead of the state ${ }^{6}$. Actually the public offerings of SOEs in this study are more similar to IPOs in the private sector than to SIPs in developed countries. Firstly, these IPOs are primary rather than secondary offerings; secondly, the capital raised from IPOs

\footnotetext{
${ }^{4}$ It is expected that the percentage of the public shares will not have much effect on the performance change under the condition that the government remains the controlling shareholder. Wang, Xu, and Zhu's (2001) finding also confirms our speculation. So we do not introduce the percentage of the public shares after going public as a control variable in the panel analysis.

${ }^{5}$ Generally, the executive directors and the managers of H-firms are mainland Chinese; they have no right to buy $\mathrm{H}-$ shares. What they can do is to buy and keep several thousand A-shares at the IPOs of A-shares, but only if their companies have A-public shares simultaneously, and they cannot trade while they are in their positions. A-shares and $\mathrm{H}-$ shares have basically the same rights according to the companies' associations.

${ }^{6}$ Only Sinopec is an exception; its state-owned parent company sold a small fraction of its existing shares in the public offering and placement of the year $2000.90 \%$ of the offering was primary offering, and $10 \%$ was secondary offering.
} 
flows to the companies rather than the original owners; and lastly, the original owners generally do not give up control rights after IPOs.

Third, all the listed $\mathrm{H}$-firms had been restructured from previously state-owned factories or companies. Such restructuring is just for listing. In the restructuring, a so-called shakeout process happened, during which social and ancillary service operations, which did not make profits, were separated from the company. It is very likely that there is a makeup effect from the shakeout process $^{7}$. Nevertheless it is expected that company performance should improve because of shakeout.

Finally, comparing the listed SOEs in mainland China (A-firms) with those in Hong Kong, the legal system of Hong Kong provides sounder protection for the minority shareholders. Although Hong Kong has been a special administration region of China (HKSAR) since 1 July 1997, Hong Kong's institutional system is very similar to that of the United Kingdom rather than that of China, as a result of its having been a British colony for a century and a half before; almost all the laws remain unchanged after the handover. The legal system is crucial to corporate governance and financing (La Porta et al., 2000; Shleifer and Vishny, 1997), which affect corporate performance. A sounder legal system and effective enforcement can bring better corporate governance practice, from which companies can benefit. Hong Kong is under the jurisdiction of common law, and common law provides sound legal protections for small investors, as in the US and UK (La Porta et al., 1997, 1998, 2000). As a result, it is expected that the performance increase (decrease) of the H-firms is larger (smaller) than for firms with only Ashares.

\footnotetext{
${ }^{7}$ As a Chinese official said, about one-third of assets and two-thirds of employees had to be separated from the restructured companies before Sinopec or Petrochina went public. (Chen Qingtai, China Economic Times (Zhong Guo Jingji Shibao), 11 Dec. 2000). For example, Sinopec Corp. was reorganized just a few months before going public. Its parent company, Sinopec Group Company, transferred to Sinopec Corp. most of its profitable petroleum and petrochemical operations. The parent retained most of the social and ancillary services operations, as well as small, unprofitable production assets and retail service stations. According to the pro forma financial statements in its public offer and placement prospectus, the net income of Sinopec Corp. in 1997, 1998, and 1999 totaled RMB 6.0 billion, (0.3) billion, and 4.7 billion respectively. However, the net income of the retained businesses within the parent company totaled RMB (3.9) billion, (4.5) billion, and (2.9) billion respectively. Thus the performance of the segments that went
} 
In addition, the performance data of these listed SOEs have high quality. The H-firms are required by the Hong Kong Exchange to provide their annual financial reports in accordance with Hong Kong or international accounting standards. And all these firms are required to recruit Hong Kong certified public accountants (most of them belonging to the "big five") as their auditors. It is reasonable to expect the data of these companies to be more reliable than those of other companies in China that are not listed overseas.

In summary, the H-firms' performance should improve due to the following factors: shakeout; Hong Kong's provision of sounder legal protection for better corporate governance; and possibly pressure from the capital market: minority shareholders distrust companies that have bad performance and remove them from their portfolios (Fama, 1980). Some other factors, such as the weakness of the revenue privatization of the H-firms, suggest that H-firms' performance should deteriorate. Although the characteristics of the $\mathrm{H}$-firms may suggest that company performance should improve, combining the analysis of the H-firms and current literature on SIPs and IPOs, we still cannot predict whether the H-firms' performance should improve or deteriorate after listing. We assume the null hypothesis is that the $\mathrm{H}$-firms performance did not change from before to after going public. The literature of corporate governance, however, suggests that the performance increase (decrease) of the H-firms will be larger (smaller) than that of the A-firms.

\subsection{Methodology}

Twelve accounting proxies are employed to measure the change of the H-firms' financial and operating performance. Table 2 presents the definitions of these twelve measures.

\section{Insert Table 2 Here}

Some explanation for these proxies is necessary. When the SOEs in China went public overseas, they became joint venture companies and qualified for income tax reductions, generally

public was much better than that of the retained businesses of the Sinopec Group. 
from $33 \%$ to $15 \%$ or even lower. Because the $\mathrm{H}$-firms are liable to different income tax rates before and after listing, we employ income before tax in calculating ROA and ROE, and income before tax and interest in calculating ROS, in order to make the pre- and postlisting data comparable.

The major performance proxies are profitability (ROS, ROA, and ROE) and operating efficiency (SALEFF, NIEFF, and AST); among them, ROS - as well as ROA, ROE, and AST to a lesser extent-is a "flow" measure and is less sensitive to inflation and accounting conventions. We place greater emphasis on these four ratios.

Following MNR, BC, and DM, we use MNR methodology as our major methodology. Also, we estimate the change of the H-firms' performance proxies before and after listing by panel analysis. For each proxy, we use the following specification:

$$
Y_{i t}=\alpha+\sum_{j=-3}^{3} \beta_{j} I P O_{j}+u_{i}+d_{t}+\varepsilon_{i t}
$$

Here subscript $t$ is the calendar year between 1991 and 2000. Subscript $j$ is the event year between -3 and +3 (the effect of the base year $j=-1$ is incorporated into $\alpha$ and will not be included in the estimation of $\beta_{j}$ ), which is the year relevant to the year of going public. The variable $Y_{i t}$ is the performance proxy such as ROA, ROE etc. for firm $i$ in the calendar year $t$. The variable $I P O_{j}$ is the dummy variable equal to one if the calendar year $t$ happens to be the event year $j$ and zero otherwise. The variables $u_{i}$ and $d_{t}$ are a firm-specific and a calendar-year-specific effect respectively. We use a firm before listing as a control for itself after listing, by using a fixed-effect model. The philosophy underlying panel analysis is similar to that of MNR methodology, that is, using the same firm before listing as a control for itself after listing. Finally, the Mann-Whitney test, which is a special case of the Kruskal- Wallis test where only two groups are 
compared, is employed to test whether the performance change of the private firms from before to after listing is different from that of the H-firms.

\section{Empirical Results and Discussions}

In this section, we present and discuss the results on the H-firms' performance change from before to after listing, summarized in table 3 and figure 1, with regard to the changes in terms of profitability, efficiency, output, employment, leverage, and dividend payout in turn.

\section{Insert Figure 1 and Table 3 Here}

\section{A. Profitability changes}

The return on sales (ROS), return on assets (ROA), and return on equity (ROE) are employed to measure profitability. In terms of ROS, panel 1 of figure 1 shows that the profitability level did not change much during the three years before listing; there was a little increase in the event year 0 and steady decrease during the three years after listing. Table 3 shows $84 \%$ of the $\mathrm{H}-$ firms experienced decrease. ROS decreased from $23.2 \%(15.4 \%)$ to $16.0 \%(7.4 \%)$ in terms of the mean (median) of the medians of the three years before and the three years after listing. The Wilcoxon signed rank test shows that the decrease is significant at the $1 \%$ level.

In terms of ROA, panel 2 of figure 1 shows that profitability level was almost the same between the event years -1 and 0 ; then it experienced substantial decrease in the following event years 1,2 , and 3 . Table 3 shows $86 \%$ of $\mathrm{H}$-firms experienced decrease. ROA decreased from $11.5 \%(8.2 \%)$ to $4.0 \%(3.5 \%)$ in terms of the mean (median) of the medians of the three years before and the three years after listing. The Wilcoxon signed rank test shows the decrease is significant at the $1 \%$ level.

Although ROS is less sensitive to inflation, ROE is more relevant to shareholders. With regard to ROE, panel 3 of figure 1 shows that profitability level experienced steady decrease 
from the event year -1 to 3 . Why did ROE decrease in the event year 0 while ROS and ROA experienced marginal increase or were unchanged? One possible reason is that when the capital from IPOs inflows to the $\mathrm{H}$-firms, it takes some time for the new capital to make a return on investment. In this sense, ROS is a more reliable indicator of the H-firms' performance change. Table 3 shows $95 \%$ of $\mathrm{H}$-firms experienced profitability decrease. ROE decreased from the dramatically high level $46.6 \%(25.3 \%)$ to a much lower level, $5.9 \%(5.8 \%)$, in terms of the mean (median) of the medians of the three years before and the three years after listing. The Wilcoxon signed rank test shows that the decrease is significant at the $1 \%$ level. Overall, there is a significant decrease in profitability between the three years before and the three years after listing.

\section{B. Efficiency Changes}

We measure operating efficiency with the sales efficiency (SALEFF, sales per employee), the net income efficiency (NIEFF, net income per employee), and the asset turnover (AST, total sales divided by total assets). All the three proxies are inflation-adjusted. AST is affected by the sharp increase in assets due to capital inflows from IPOs. SALEFF and NIEFF are affected by the restructuring in which the government separates redundant employees and nonproductive assets from the firms before listing. From the standpoint of shareholders, net income is more relevant than real sales, so NIEFF is more relevant than SALEFF.

As regards sales efficiency (SALEFF), table 3 shows it increased from $0.904(0.932)$ to $0.958(0.938)$ in terms of the mean (median) of the medians of the three years before and the three years after listing. However, the Wilcoxon signed rank test shows that the increase is not significant even at the $10 \%$ level.

As regards net income efficiency (NIEFF), table 3 shows $76 \%$ of the $\mathrm{H}$-firms experienced a decrease in operating efficiency. NIEFF decreased from $0.713(0.790)$ to $0.494(0.456)$ in terms of the mean (median) of the medians of the three years before and the three years after 
listing. The Wilcoxon signed rank test shows the decrease is statistically significant at the $1 \%$ level, and it is also economically significant.

As regards asset turnover (AST), panel 4 of figure 1 shows that the operating efficiency experienced steady decrease from the event year -1 to 3 . Table 3 shows $78 \%$ of the $\mathrm{H}$-firms experienced decrease in AST. It decreased from $0.748(0.640)$ to $0.458(0.405)$ in terms of the mean (median) of the medians of the three years before and the three years after listing. The Wilcoxon signed rank test shows the decrease is significant at the $1 \%$ level.

\section{Changes in Output}

We employ inflation-adjusted total sales (SAL) to measure the changes in output. Panel 5 of figure 1 shows that output experienced a gradual and steady increase from the event year -3 to +3 . Table 3 shows that around $71 \%$ of $\mathrm{H}$-firms experienced output increase after listing. SAL increased from $0.821(0.871)$ to $1.066(1.000)$ in terms of the mean (median) of the medians of the three years before and the three years after listing. Furthermore, the Wilcoxon signed rank test shows the increase is significant at the $1 \%$ level.

\section{Employment Changes}

The government is concerned about the employment changes for listed SOEs other than the shareholders. Most H-firms underwent the restructuring process before listing, during which the government separates redundant employees. So it is not plausible to attribute the employment change solely to the IPO or privatization effect. However, table 3 shows total employment changes from $12,570(8102)$ to 11,323 (7283) in terms of the mean (median) of the medians of the three years before and the three years after listing: the mean increases and the median decreases. Anyway, the Wilcoxon signed rank test shows the increase (or decrease) is not significant at the $10 \%$ level. The big difference between median and mean shows that the distribution of total employment in the H-firms is highly asymmetrical. We can safely say the H-firms' 
employment did not increase nor decrease much after listing.

\section{E. Changes in Leverage}

We examine changes in leverage proxied by changes in the ratio of total debt to total assets (LEV) and changes in the ratio of long-term debt to equity (LEV2).

As regards LEV, table 3 shows $97 \%$ of the $\mathrm{H}$-firms experienced a decrease in debt to assets ratio. LEV decreased from $0.656(0.659)$ to $0.412(0.389)$ in terms of the mean (median) of the medians of the three years before and the three years after listing. The Wilcoxon signed rank test shows the decrease is significant at the $1 \%$ level.

As regards LEV2, table 3 shows $84 \%$ of $\mathrm{H}$-firms experienced a decrease in long term debt to equity ratio. LEV2 decreased from the dramatically high level $1.421(0.634)$ to the relatively low level $0.339(0.136)$ in terms of the mean (median) of the medians of the three years before and the three years after listing. The Wilcoxon signed rank test shows the decrease is significant at the $1 \%$ level.

\section{F. Changes in Dividend Payouts}

As a final test, we examine the dividend payout change measured as DIVSAL (cash dividend divided by sales revenue) and PAYOUT (cash dividend divided by net income).

Table 3 shows that DIVSAL increased from 0.009 (0) to $0.057(0.019)$ in terms of the mean (median) of the medians of the three years before and the three years after listing. The Wilcoxon signed rank test shows the increase is significant at the $1 \%$ level, and it is also economically significant.

Panel 6 of figure 1 shows that dividend payout experienced similar changes to DIVSAL. Table 3 shows that PAYOUT increased from $0.133(0.00)$ to $0.357(0.353)$ in terms of the 
mean (median) of the medians of the three years before and the three years after listing. The Wilcoxon signed rank test shows the increase is significant at the $1 \%$ level, and it is also economically significant.

\section{Robustness Analyses}

Besides the MNR methodology, we employ the following methods to do robustness checks. First, as with the MNR methodology, we find that even the maximum level of the H-firms' performance during the three years after listing, in terms of ROS, ROA, ROE, and AST, is lower than that of the event year -1 , and for NIEFF and SALEFF, the maximum level during the three years after listing is higher than that in the event year -1 , but not significant at the $5 \%$ level $^{8}$.

Second, we use OLS analysis with dummy variables and with firm-specific fixed effect (panel analysis) to estimate the effect of listing on the H-firms' performance as shown in table 4. For each performance proxy, we perform an $F$-test on the hypothesis that the parameters of all the event years are the same, or the parameters of event years 2 and 3 are the same. Specifically, the second hypothesis test is used to test whether or not the listing effect faded away within three years. For each performance proxy, as the parameter of the event year -1 is incorporated into the intercept, the level in the event year -1 is regarded as a benchmark. When the estimated parameter for, say, the event year 1 is positive (negative), it means that the performance proxy improves (deteriorates) compared to that in the event year -1 . Generally the panel analysis results are consistent with the results of the MNR methodology.

\section{Insert Table 4 Here}

On the subject of profitability change, table 4 shows that the ROS's level can be the same in the event years $-3,-2,-1$, and the ROS experienced a marginal increase in the event year 0 , not significant at the $10 \%$ level. However, its decrease in the event year 1 is significant at the $5 \%$ level,

\footnotetext{
${ }^{8}$ The related table is available upon request.
} 
and its decreases in the event years 2 and 3 are both statistically significant at the $1 \%$ level and economically significant. The ROA experienced a marginal decrease in the event year 0 without statistical or economic significance. However, its decreases in the event years 1, 2, and 3 are both statistically significant at the $1 \%$ level and economically significant. The ROE decreases in the event years $0,1,2$, and 3 are statistically significant at the $1 \%$ level, and they are also economically significant.

On the subject of efficiency change, both NIEFF and AST decreased after listing, while SALEFF did not. In terms of sales efficiency (SALEFF), the parameters of the event year 0,1 , and 2 can be zero, which means the level of sales efficiency did not change much between the event years -1 and 2 . However, the parameter of the event year 3 dummy is significantly positive at the $1 \%$ level. The net income efficiency (NIEFF) increased in the event year 0 and then decreased in the event years 1, 2, and 3. However, neither the increase in the event year 1 nor the decrease in the event years 1 and 3 is significant at the $5 \%$ level; only the decrease in the event year 2 is significant at the 5\% level. With regard to asset turnover (AST), consistent with the nonparametric analysis, AST decreased in the event years $0,1,2$, and 3 compared to the event year -1 , and the decreases are statistically significant at the $1 \%$ level and are also economically significant.

On the subject of output change in terms of SAL, the parameters of the event years -3 to +3 gradually increased from -0.165 to 0.257 , indicating that real sales had been growing around the listing. On the subject of employment changes, the increase or decrease in the event year $0,1,2$, or 3 compared with the event year -1 is not significant at the $10 \%$ level. Actually the event year dummy variables have no explanatory power for employment. We can safely say that the total employment remained unchanged after listing.

On the subject of leverage change, the decrease in LEV from the event year -1 to $0,1,2$, or 3 is significant at the $1 \%$ level. Furthermore, the $F$-test shows the parameters of the event years 1,2 , and 3 to be same at the $5 \%$ level. That is also the case when we use LEV2 to 
measure leverage. That is, the decrease in LEV2 from the event year -1 to $0,1,2$, or 3 is significant at the $1 \%$ level, and the $F$-test shows that the parameters of the event years 1,2 , and 3 are the same at the $5 \%$ level. This means that the decrease of leverage is mainly due to the inflow of new capital raised from going public.

On the subject of dividend payout, in terms of DIVSAL (ratio of cash dividend to sales), the dividend payout in the event years $-3,-2$, and -1 is the same, but it is increased in the event years $0,1,2$, and 3 compared with the event year -1 , and these increases are not only statistically significant at the $1 \%$ level but also economically significant. The result of the analysis of PAYOUT is very similar to that of DIVSAL, although the event year dummy variables have not much explanatory power. We argue that market discipline controls the dividend payout: $\mathrm{H}$-firms tend to increase their dividend payout after going public.

Overall, $F$-tests show that the event year dummy variables have explanatory power in 10 out of these 12 proxies (the exceptions are EMPL and PAYOUT). Additionally, a new important result emerged from panel analysis: we have strong evidence that the listing effect fades away within three years. Tests of the hypothesis that the parameters of the event year 2 and 3 dummy variables are the same hold in the analysis of ROS, ROA, ROE, AST, EMPL, LEV, LEV2, DIVSAL, and PAYOUT. Only those in the analysis of SALEFF, SAL, and NIEFF do not hold. The reason is, as we will point out later, that the economic growth effect is dominant over the listing effect for these three proxies.

Third, in panel analysis, $F$-tests show that the event year dummy variables are more powerful than the calendar year dummy variables for the H-firms' performance change ${ }^{9}$. The calendar year dummy can be regarded as a proxy for external factors, while the event year dummy represents the listing effect, which is the overall effect of revenue privatization and IPO. So we

\footnotetext{
9 The related table is available upon request.
} 
can conclude that the H-firms' performance change is mainly due to the IPO and privatization effects.

Fourth, as we find that the performance of the newly listed H-firms became worse and the recent literature has shown that that is also the case in the private sector, we now propose to test whether there is any difference between the performance change of newly listed private companies and that of the H-firms. Table 5 summarizes the results of Mann-Whitney tests. As we don't have enough employment data about the control firms, we cannot compare the sales efficiency or the net income efficiency.

\section{Insert table 5 here}

Table 5 shows, surprisingly, that the downward performance change of the private firms on going public is larger than that of the H-firms. Firstly, the four most important performance proxies (ROS, ROA, ROE, and AST) of the control firms decreased more than those of the Hfirms. Although the decrease is not significantly different at the 5\% level for ROS or AST, both the ROA and ROE changes are significantly different at the 5\% level. Actually, the ROA and ROE of the control firms are higher than those of the $\mathrm{H}$-firms before listing; the relation, however, is reversed after listing. Secondly, the control firms have greater real sale growth (although the difference is not significant), which implies that the control firms have at least as good a growth opportunity as the H-firms. Thirdly, the dividend in terms of DIVSAL or PAYOUT increased for the $\mathrm{H}$-firms, but decreased for the control firms. We argue that the managers of $\mathrm{H}$-firms are more sensitive to the market pressure from the public shareholders than are those of the control firms.

Why is the performance decline of the control firms worse than that of the H-firms? Firstly, the corporatization restructuring before listing may have that effect: As the $\mathrm{H}$-firms become limited corporations consistent with the international standard, they have to disclose important management events and financial statements regularly. The listed companies at least legally 
adopt profit or shareholder wealth maximization as their first priority. Secondly, the managers/directors of the $\mathrm{H}$-firms are more sensitive to market pressure from the public shareholders and institutional investors than their counterparts of the control firms, because their job security is smaller. The general managers of the control firms are generally larger shareholders even if not controlling shareholders. That is especially true for the early years of these newly listed companies: they have actual control over the general meeting and the board meeting. The managers of the $\mathrm{H}$-firms, in contrast, are at most minor shareholders with a few thousand shares. They have less job security than their counterparts in control firms if the market (other shareholders or financial analysts) strongly opposes them. Strong evidence from table 5 is that Hfirms' dividend payout increased more than that of the control group after listing, as the payout level of $\mathrm{H}$-firms before listing is lower than that of the controls. To summarize, legal establishment of the goal of shareholder wealth maximization and increase in market pressure both result from privatization.

Finally, we compare performance change among the H-firms, control firms, and A-firms to test whether Hong Kong is a better place for Chinese SOEs to go public from the perspective of corporate governance. Rigorous comparison is impossible, as the accounting rules in Hong Kong are different from those in China and China's accounting rules have been changing rapidly in recent years. Here we simply obtain A-firms' performance change from Wang, $\mathrm{Xu}$, and Zhu (2001) to compare with what we have in our study. As only one performance proxy, ROS, is used both by Wang, $\mathrm{Xu}$, and $\mathrm{Zhu}$ (2001) and in this paper with same definition, ROS is used to compare these three types of firms with respect to performance change as listed in table 6 . 
Table 6 Return on Sales for the H-, A-, and Control Firms

\begin{tabular}{lcccccc}
\hline & No. & $\mathrm{Y}-1$ & $\mathrm{Y} 0$ & $\mathrm{Y} 1$ & $\mathrm{Y} 2$ & $\mathrm{Y} 3$ \\
\hline A-firms & 285 & $0.166(100)$ & $0.162(97.6)$ & $0.137(82.5)$ & $0.078(47.0)$ & $0.044(26.5)$ \\
Control Firms & 38 & $0.172(100)$ & $0.163(94.8)$ & $0.085(49.4)$ & $0.013(7.6)$ & $0.035(20.0)$ \\
H-firms & 38 & $0.239(100)$ & $0.272(113.8)$ & $0.196(82.1)$ & $0.163(68.2)$ & $0.125(52.3)$ \\
\hline
\end{tabular}

Notes: (1) Data for A-firms are from Wang, $\mathrm{Xu}$, and $\mathrm{Zhu}$ (2001).

(2) No. is the number of observations, and $\mathrm{Y}-1, \mathrm{Y} 0, \mathrm{Y} 1, \mathrm{Y} 2, \mathrm{Y} 3$ are event years relative to the year of going public.

Table 6 shows that the performance of control firms also decreased more than that of Afirms. In the year before going public, the ROS of control firms is higher than that of A-firms, but the relation is reversed in the years 1,2, and 3 after going public. As most of the A-firms are also newly revenue-privatized firms, the positive privatization effect is expected to be one of the reasons. Comparing the $\mathrm{H}$-firms with the A-firms, table 6 shows that the performance of the Afirms seems to decrease more than that of the $\mathrm{H}$-firms in the years 1,2, and 3 after going public. The sound legal system and strong market discipline may explain the difference. Hong Kong seems to be a better place for Chinese SOEs to go public from the perspective of sounder corporate governance.

\section{Conclusions}

This study compares the financial and operating performance before and after going public for the complete sample of the H-firms listed in Hong Kong, by employing MNR methodology and panel analysis. The results of nonparametric analysis are consistent with panel analysis, and our results pass several robustness checks. Our major findings are summarized as follows.

(1) Real sales (SAL) gradually increased before and after going public. The trend and rate of the growth did not change much. Being that of a developing country, the Chinese economy has been growing very fast: the average growth rate of GDP between 1990 and 1999 was $10.7 \%$, 
while that of the whole world was $2.5 \%{ }^{10}$. We argue that the gradual increase in the real output is mainly due to China's economic growth instead of the listing effect. Sales efficiency (SALEFF) has a similar problem, as it is computed from real sales divided by total employment. Furthermore, that means the external operating environment of the H-firms after listing did not deteriorate. We cannot attribute the H-firms' performance deterioration to worsened external environment.

(2) Dividend payout (measured by DIVSAL and PAYOUT) increased after listing. This shows that market discipline may work and the H-firms' corporate governance may have improved. Employment remains roughly steady before and after listing. The restructuring process in preparation for listing involved a cut in employees; we cannot attribute the change of employment to a privatization or IPO effect. One possible explanation is that the government does not want these firms to lay off more employees while it retains control.

(3) Return on sales (ROS), return on assets (ROA), return on equity (ROE), net income efficiency (NEIEFF), and asset turnover (AST) are employed to measure the change of the operating performance (profitability and efficiency) for the H-firms. Generally the operating performance marginally increased (except ROE) in the event year 0 and then experienced statistically and economically significant decrease in the following three years compared to the level of the event year -1 . However, the performance decline of the firms is smaller than that of the control group, and the listing effect faded out within three years. This shows that, although the negative IPO effect dominates the positive privatization effect in the H-firms' performance change and the overall effect of IPO and privatization is negative, the positive privatization effect did somewhat offset the negative IPO effect.

This study has at least two important policy implications. First, listing Chinese SOEs is still recommended, even though it is only revenue privatization and the company's performance declines in the short run, because the privatization effect is still positive if we deduct

\footnotetext{
${ }^{10}$ World Bank, www.worldbank.org/poverty/wdrpoverty/report
} 
the IPO effect, and the decrease faded away within three years. Second, Hong Kong seems to be a better place than Shanghai or Shenzhen for Chinese SOEs to go public, as it can provide a better legal system, which is helpful for sound corporate governance. 


\section{References}

Boardman, Anthony E. and Aidan R. Vining, 1989, Ownership and performance in competitive environments: a comparison of the performance of private, mixed and state-owned enterprises, Journal of Law and Economics 32,1-33.

Bourakri, Narjess and Jean-Claude Cosset, 1998, The financial and operating performance of newly privatized firms: evidence from developing countries, Journal of Finance 53, 10811110 .

Chen, Gongmeng, Michael Firth, and Jeong-Bon Kim, 2000, The post-issue market performance of initial public offerings in China's new stock market, Review of Quantitative Finance and Accounting, 14(4), 319-339.

D'Souza, Juliet, and William L. Megginson, 1999, The financial and operating performance of privatized firms during the 1990s, Journal of Finance 54, 1397-1438.

Fama, Eugene F., 1980, Agency problems and the theory of the firm, Journal of Political Economy, $88,288-307$

Jain, Bharat A., and Omesh Kini, 1994, The post-issue operating performance of IPO firms, Journal of Finance 49, 1699-1726.

Jenson, Michael, and William Meckling, 1976, Theory of the firm: managerial behavior, agency costs, and ownership structure, Journal of Financial Economics 3, 305 - 360.

Jones, Steven L., William L. Megginson, Robert C. Nash, and Jeffry M. Netter, 1999, Share issue privatizations as financial means to political and economic ends, Journal of Financial Economics 53, 217-253.

La Porta, Rafel, Florencio Lopez-de-silanes, and Andrei Shlerifer, 1997, Legal determinants of external finance, Journal of Finance 52, 1131-1150.

La Porta, Rafel, Florencio Lopez-de-silanes, and Andrei Shlerifer, 1998, Law and finance, Journal of Political Economy 106, 1113-1155.

La Porta, Rafel, Florencio Lopez-de-silanes, and Andrei Shlerifer, 2000, Investor protection and corporate governance, Journal of Financial Economics 58, 3 - 27.

Loughran, Tim, and Jay R. Ritter, 1995, The New Issue Puzzle, Journal of Finance, 50(1),23-51.

Loughran, Tim, Jay R. Ritter, and Kristian Rydqvist, (1994),1997, Initial public offerings: International insights, Pacific-Basin Finance Journal 2, 165-199.

Megginson, William L., Robert C. Nash, and Matthias Van Randenborgh, 1994, The financial and operating performance of newly privatized firms: an international empirical analysis, Journal of Finance 49, 403-452

Megginson, L. William, and Jeffry M. Netter, 2001, From state to market: a survey of empirical studies on privatization. Journal of Economic Literature, 39(2), 321-389.

Mikkelson, Wayne H., Megan Partch, and Hen performance of companies that go

Shah, 1997, Ownership and operating

public, Journal of Financial Economics 44, 
281-308.

Neter, John, William Wasserman, and G.A. Whitmore, 1993, Applied Statistics. Fourth edition (Allyn and Bacon).

Pagano, Marco, Fabio Panetta, and Luigi Zingales, 1998, Why do companies go public? An empirical analysis, Journal of Finance 53, 27-64.

Rajan, Raghuram G., and Henri Servaes, 1997, The effect of market conditions on initial public offerings, Journal of Finance 52, 507-529.

Ritter, Jay R., 1991, The long-run performance of initial public offerings, Journal of Finance 46, $3-27$.

Shleifer, Andrei, and Robert W. Vishny, 1997, A survey of corporate governance, Journal of Finance, 52, $737-783$.

Teoh, Siew Hong, Ivo Welch, and T. J. Wong, 1998, Earnings management and the long-run market performance of initial public offerings, Journal of Finance 53, 1935-1974.

Wang, Xiaozu, Lixin Colin Xu, and Tian Zhu, Is Public Listing a Way out for State-Owned Enterprises? The Case of China, manuscript, September 2001.

$\mathrm{Xu}$, Xiaonian, and Yan Wang, 1999, Ownership structure and corporate governance in Chinese stock companies, China Economic Review 10(1),75-98. 


\section{Table 1 Basic Facts on the H-firms and the Control Firms}

This table presents the basic facts on the $\mathrm{H}$-firms and the control firms in terms of real sales, total assets, equity, and the number of the employees in the event years -1 and 0 . Sales, total assets, and equity are deflated by the Chinese total consumer price index (base period: 1990) for the H-firms, and by the Hong Kong consumer price index (base period: October 1989 to September 1990) for the control firms; their units are RMB1000 and HK\$1000 respectively. HK\$1 is around RMB1.06. US\$1 is around HK\$7.8. Both the H-firms and the control firms went public on the Hong Kong Exchange between 1993 and 1998. The employment data are not available in the event year 0 for the control firms.

\begin{tabular}{cccc}
\hline & Items & H-Firms & Control Firms \\
\hline No. of Firms & & 38 & 38 \\
\hline Event Year -1 & & & \\
\hline SAL & Mean & 1560252 & 340035 \\
& Stdev & $(1438591)$ & $(292647)$ \\
Total Assets & Mean & 2878075 & 465398 \\
& Stdev & $(3065633)$ & $(815515)$ \\
Equity & Mean & 878091 & 146440 \\
& Stdev & $(809396)$ & $(376232)$ \\
EMPL & Mean & 12570 & 1347 \\
& Stdev & $(12770)$ & $(1966)$ \\
\hline Event Year 0 & & & \\
\hline SAL & Mean & 1703117 & 449475 \\
& Stdev & $(1664678)$ & $(326194)$ \\
Total Assets & Mean & 3961429 & 942230 \\
& Stdev & $(3841778)$ & $(1964284)$ \\
Equity & Mean & 2139849 & 569534 \\
& Stdev & $(1829012)$ & $(1251219)$ \\
\hline
\end{tabular}


Table 2 Definitions of the Financial and Operating Performance Measures

Variables

Definitions

ROS Return on Sales: Operating profit divided by total sales. Operating profit is income before tax, interest, and extraordinary items.

ROA Return on Assets: Net income before tax divided by the book value of total assets. Total assets are the average of the current and previous year if possible.

ROE Return on Equity: Net income before tax divided by shareholders' equity. Equity is the average of the current and previous year if possible.

SALEFF Sales Efficiency: Real sales divided by number of employees. Real sales is book sales divided by China's total consumer price index. Sales efficiency is normalized to the base of the event year 0 . That is, we let sales efficiency in the event year 0 be 1.000 .

NIEFF Net Income Efficiency: Real net income before tax divided by number of employees. Real net income before tax is net income before tax divided by China's total consumer price index. Net income efficiency is normalized similarly to sales efficiency for comparison purposes.

AST

Asset Turnover: Total sales divided by total assets. Total assets are the average of the current and previous year if possible.

SAL Real Sales: Total sales reported in the financial statements divided by China's total consumer price index. China's total consumer price index is employed because H-firms' business is mainly in China.

EMPL Total Number of Employees: Number of employees is not a compulsory disclosure item, so not all the firms publish it.

LEV Debt to Assets Ratio: Ratio of total debt to total assets. Total assets are calculated as short-term debt plus long-term debt plus shareholders' equity. Spot ratio.

LEV2 Long-term Debt to Equity Ratio: Ratio of long-term debt to shareholders' equity. Spot ratio.

DIVSAL Ratio of Dividends to Sales: Cash dividends divided by total sales.

PAYOUT Dividend Payout: Cash dividends divided by net income. Net income is income after tax and interest. 


\section{Table 3: Summary of the Tests on the H-firms' Performance Change by MNR Methodology}

This table presents empirical results for H-firms' performance changes in terms of three years' median before versus after going public. The table presents, for each accounting measure, the number of usable observations, the mean and median values of the median for the three-year periods prior and subsequent to going public, the mean and median change in the measure's value on going public, and tests of significance of the median change. Not all the six years' accounting measure data are available, because some items are not compulsory in corporations' public offer and placement prospectuses and because some firms have not presented their third annual reports after going public. For each proxy, median values are presented in parentheses just under the mean values. We employ Wilcoxon signed rank test with their $S$-statistic and $P$-value as our tests of significance for the change in the median values. The final three columns present the percentage of firms whose proxy values change as noted, as well as a test of significance and its $P$-value for this change. Finally, sales efficiency, net income efficiency, and real sales use inflation-adjusted proxies in which China's total consumer price index is employed. Deflated proxies are normalized to equal to 1.000 in the event year 0 (base year), so the other year figures are expressed as fractions of base year figures. As regards the Wilcoxon signed rank test, although when the sample size employed is sufficiently large, the normal distribution can be used to approximate the Wilcoxon $S$-statistic, SAS software computes the significance level of $S$ from its exact distribution, which is given by a convolution with a scaled binomial distribution when $n$, the number of nonzero proxy differences, is less than or equal 20, or from approximate Student's $t$ with $n-1$ degrees of freedom when $n$ is more than 20 . 
Table 3: Summary of the Tests on the H-firms' Performance Change by MNR Methodology(Continued)

\begin{tabular}{|c|c|c|c|c|c|c|c|c|c|}
\hline Variables & & $\begin{array}{l}\text { ean } \\
\text { Uedian) } \\
\text { efore }\end{array}$ & $\begin{array}{l}\text { Mean } \\
\text { (Median) } \\
\text { After }\end{array}$ & $\begin{array}{l}\text { Median } \\
\text { Change }\end{array}$ & $\begin{array}{l}S \text {-Statistic for } \\
\text { Difference in } \\
\text { Means } \\
\text { (After-Before) }\end{array}$ & $\begin{array}{l}P \text {-value for } \\
\text { Wilcoxon Test }\end{array}$ & $\begin{array}{l}\text { Percentage of } \\
\text { Firms That } \\
\text { Changed as in } \\
\text { Notes* }\end{array}$ & $\begin{array}{l}\text { Z-Statistic for } \\
\text { Significance of } \\
\text { Proportion Change }\end{array}$ & $\begin{array}{l}P \text {-value for } \\
\text { Proportion Test }\end{array}$ \\
\hline \multicolumn{10}{|l|}{ PROFITABILITY } \\
\hline Return on Sales & 38 & $\begin{array}{c}0.232 \\
(0.154)\end{array}$ & $\begin{array}{c}0.160 \\
(0.074)\end{array}$ & $\begin{array}{c}-0.072 \\
(-0.069)\end{array}$ & -276.5 & 0.00 & 84.21 & 4.22 & $<0.0001$ \\
\hline Return on Assets & 37 & $\begin{array}{c}0.115 \\
(0.082)\end{array}$ & $\begin{array}{c}0.040 \\
(0.035)\end{array}$ & $\begin{array}{c}-0.075 \\
(-0.056)\end{array}$ & -300.5 & 0.00 & 86.49 & 4.44 & $<0.0001$ \\
\hline Return on Equity & 37 & $\begin{array}{c}0.466 \\
(0.253)\end{array}$ & $\begin{array}{c}0.059 \\
(0.058)\end{array}$ & $\begin{array}{c}-0.407 \\
(-0.223)\end{array}$ & -343.5 & 0.00 & 94.59 & 5.43 & $<0.0001$ \\
\hline \multicolumn{10}{|l|}{ EFFICIENCY } \\
\hline Sales Efficiency & 24 & $\begin{array}{c}0.904 \\
(0.932)\end{array}$ & $\begin{array}{c}0.958 \\
(0.938)\end{array}$ & $\begin{array}{c}0.043 \\
(0.056)\end{array}$ & 9 & 0.80 & 41.67 & -0.82 & 0.4142 \\
\hline Net Income Efficiency & 25 & $\begin{array}{c}0.713 \\
(0.790)\end{array}$ & $\begin{array}{c}0.494 \\
(0.456)\end{array}$ & $\begin{array}{c}-0.233 \\
(-0.380)\end{array}$ & -83.5 & 0.02 & 76 & 2.6 & 0.0093 \\
\hline Asset Turnover & 37 & $\begin{array}{c}0.748 \\
(0.640)\end{array}$ & $\begin{array}{c}0.458 \\
(0.405)\end{array}$ & $\begin{array}{c}-0.281 \\
(-0.188)\end{array}$ & -291.5 & 0.00 & 78.38 & 3.45 & 0.0006 \\
\hline
\end{tabular}


Table 3: Summary of the Tests on the H-firms' Performance Change by MNR Methodology(Continued)

\begin{tabular}{|c|c|c|c|c|c|c|c|c|c|}
\hline Variables & & $e^{(\text {Median})}$ & $\begin{array}{l}\text { Mean } \\
\text { (Median) } \\
\text { After }\end{array}$ & $\begin{array}{l}\text { Median } \\
\text { Change }\end{array}$ & $\begin{array}{l}S \text {-Statistic for } \\
\text { Difference in } \\
\text { Means } \\
\text { (After-Before) }\end{array}$ & $\begin{array}{l}P \text {-value for } \\
\text { Wilcoxon } \\
\text { Test }\end{array}$ & $\begin{array}{l}\text { Percentage of } \\
\text { Firms That } \\
\text { Changed as in } \\
\text { Notes* }\end{array}$ & $\begin{array}{l}Z \text {-Statistic for } \\
\text { Significance of } \\
\text { Proportion } \\
\text { Change }\end{array}$ & $\begin{array}{l}P \text {-value for } \\
\text { Proportion } \\
\text { Test }\end{array}$ \\
\hline \multicolumn{10}{|l|}{ OUTPUT } \\
\hline Real Sales & 38 & $\begin{array}{c}0.821 \\
(0.871)\end{array}$ & $\begin{array}{c}1.066 \\
(1.000)\end{array}$ & $\begin{array}{c}0.245 \\
(0.169)\end{array}$ & 220.5 & 0.00 & 28.95 & -2.6 & 0.0094 \\
\hline \multicolumn{10}{|l|}{ EMPLOYMENT } \\
\hline Total Employment & 23 & $\begin{array}{l}12570 \\
(8102)\end{array}$ & $\begin{array}{l}11323 \\
(7283)\end{array}$ & $\begin{array}{l}184 \\
(97)\end{array}$ & 25 & 0.46 & 39.13 & -1.04 & 0.2971 \\
\hline \multicolumn{10}{|l|}{ LEVERAGE } \\
\hline Debt to Assets & 37 & $\begin{array}{c}0.656 \\
(0.659)\end{array}$ & $\begin{array}{c}0.412 \\
(0.389)\end{array}$ & $\begin{array}{c}-0.237 \\
(-0.199)\end{array}$ & -347.5 & 0.00 & 97.3 & 5.75 & $<0.0001$ \\
\hline Long-term Debt to Equity & 37 & $\begin{array}{c}1.421 \\
(0.634)\end{array}$ & $\begin{array}{c}0.339 \\
(0.136)\end{array}$ & $\begin{array}{c}-0.312 \\
(-0.473)\end{array}$ & -250.5 & 0.00 & 83.78 & 4.11 & $<0.0001$ \\
\hline \multicolumn{10}{|l|}{ DIVIDENDS } \\
\hline Dividends to Sales & 38 & $\begin{array}{c}0.009 \\
(0.000)\end{array}$ & $\begin{array}{c}0.057 \\
(0.019)\end{array}$ & $\begin{array}{c}0.048 \\
(0.016)\end{array}$ & 175.5 & 0.00 & 75.76 & 2.96 & 0.0031 \\
\hline Dividend Payout & 37 & $\begin{array}{c}0.133 \\
(0.000)\end{array}$ & $\begin{array}{c}0.357 \\
(0.353)\end{array}$ & $\begin{array}{c}0.228 \\
(0.255)\end{array}$ & 160 & 0.00 & 78.12 & 3.18 & 0.0015 \\
\hline
\end{tabular}

Notes: For dividends, the percentage is that of firms which experienced increase. For $\quad$ all the other proxies, the percentage is that of firms which experienced decrease. 


\section{Table 4: Summary of Panel Data Analysis Results for the H-firms' Performance Change}

This table summarizes the results of panel data analysis for the H-firms' performance change. The model employed for each accounting measure is described in the Data and Methodology session. The calendar year dummy variables are not included in the model employed. The table presents, for each accounting measure, the number of usable observations, the estimator of the intercept, and the estimators of the parameters of the dummy variables for the event years -3 , -2 (if available), $0,1,2$, and 3. The last three columns display $R^{2}, F$-test(1), and $F$-test(2). The number of degrees of freedom, $F$-value, and $P$-value are given under the columns of $F$-test(1) and $F$-test(2). $F$-test(1) is the test of the hypothesis that all the event year variables have no explanatory power: that all the parameters of the event year are zero. $F$-test(2) is the test of the hypothesis that the parameters of the dummy variables for the event years 2 and 3 are the same, that is, the effect of listing does not last beyond three years. For each estimator, the $T$-value and $P$-value are represented following the estimator. For some performance proxies, $F$-tests of the hypothesis that the parameters of the event years 1,2, and 3 are the same are presented in the notes. 
Table 4: Summary of Panel Data Analysis Results for the H-firms' Performance Change

\begin{tabular}{|c|c|c|c|c|c|c|c|c|c|c|c|}
\hline Variables & $N$ & Intercept & EventYear -3 & EventYear -2 & EventYear 0 & EventYear 1 & EventYear 2 & EventYear 3 & $R^{2}$ & $F$-Test $(1)$ & $F$-Test(2) \\
\hline Return on Sales & 265 & 0.179 & -0.010 & 0.005 & 0.032 & -0.043 & -0.086 & -0.111 & 0.864 & $(6,221)$ & $(1,221)$ \\
\hline$T$-value & & 4.700 & -0.470 & 0.250 & 1.510 & -2.020 & -4.030 & -5.130 & & 11.7 & 1.29 \\
\hline$P$-value & & $<0.0001$ & 0.637 & 0.799 & 0.133 & 0.045 & $<0.0001$ & $<0.0001$ & & 0.000 & 0.258 \\
\hline Return on Assets & 188 & 0.136 & & & -0.003 & -0.060 & -0.076 & -0.078 & 0.656 & $(4,146)$ & $(1,146)$ \\
\hline$T$-value & & 6.080 & & & -0.300 & -5.430 & -6.910 & -7.030 & & 24.87 & 0.03 \\
\hline$P$-value & & $<0.0001$ & & & 0.767 & $<0.0001$ & $<0.0001$ & $<0.0001$ & & 0.00 & 0.86 \\
\hline Return on Equity & 188 & 0.434 & & & -0.246 & -0.371 & -0.402 & -0.367 & 0.408 & $(4,146)$ & $(1,146)$ \\
\hline$T$-value & & 2.910 & & & -3.350 & -5.060 & -5.480 & -4.960 & & 10.16 & 0.22 \\
\hline$P$-value & & 0.004 & & & 0.001 & $<0.0001$ & $<0.0001$ & $<0.0001$ & & 0.00 & 0.64 \\
\hline Sales Efficiency & 121 & 0.772 & & & 0.050 & -0.005 & -0.023 & 0.562 & 0.368 & $(4,92)$ & $(1,92)$ \\
\hline$T$-value & & 2.420 & & & 0.290 & -0.030 & -0.130 & 3.220 & & 4.3 & 11.61 \\
\hline$P$-value & & 0.017 & & & 0.776 & 0.976 & 0.895 & 0.002 & & 0.00 & 0.00 \\
\hline Net Income Efficiency & 127 & 0.934 & & & 0.143 & -0.323 & -0.557 & -0.067 & 0.460 & $(4,95)$ & $(1,95)$ \\
\hline$T$-value & & 2.990 & & & 0.860 & -1.890 & -3.250 & -0.400 & & 5.6 & 8.62 \\
\hline$P$-value & & 0.004 & & & 0.391 & 0.062 & 0.002 & 0.694 & & 0.00 & 0.00 \\
\hline Asset Turnover & 188 & 1.145 & & & -0.161 & -0.277 & -0.282 & -0.283 & 0.821 & $(4,146)$ & $(1,146)$ \\
\hline$T$-value & & 14.55 & & & -4.15 & -7.18 & -7.29 & -7.26 & & 20.29 & 0 \\
\hline$P$-value & & $<0.0001$ & & & $<0.0001$ & $<0.0001$ & $<0.0001$ & $<0.0001$ & & 0.00 & 0.97 \\
\hline
\end{tabular}


Table 4: Summary of Panel Data Analysis Results for the H-firms' Performance Change (Continued)

\begin{tabular}{|c|c|c|c|c|c|c|c|c|c|c|c|}
\hline Variables & $N$ & Intercept & EventYear -3 & EventYear -2 & EventYear 0 & EventYear 1 & EventYear 2 & EventYear 3 & $R^{2}$ & $F$-Test $(1)$ & $F$-Test $(2)$ \\
\hline Real Sales & 265 & 1.039 & -0.165 & -0.103 & 0.075 & 0.075 & 0.133 & 0.257 & 0.436 & $(6,221)$ & $(1,221)$ \\
\hline$T$-value & & 9.570 & -2.690 & -1.680 & 1.230 & 1.230 & 2.180 & 4.170 & & 10.74 & 4.03 \\
\hline$P$-value & & $<0.0001$ & 0.008 & 0.095 & 0.220 & 0.221 & 0.031 & $<0.0001$ & & 0.00 & 0.05 \\
\hline Total Employment & 128 & 10215 & & & 121 & 273 & 104 & -118 & 0.994 & $(4,95)$ & $(1,95)$ \\
\hline$T$-value & & 15 & & & 0.400 & 0.890 & 0.340 & -0.380 & & 0.46 & 0.54 \\
\hline$P$-value & & $<0.0001$ & & & 0.687 & 0.377 & 0.736 & 0.706 & & 0.76 & 0.47 \\
\hline Debt to Asset & 188 & 0.518 & & & -0.260 & -0.249 & -0.229 & -0.218 & 0.848 & $(4,146)$ & $(1,146)$ \\
\hline$T$-value & & 12.540 & & & -12.780 & -12.280 & -11.260 & -10.630 & & 56.09 & 0.28 \\
\hline$P$-value & & $<0.0001$ & & & $<0.0001$ & $<0.0001$ & $<0.0001$ & $<0.0001$ & & 0.00 & 0.60 \\
\hline Long Term Debt to Equity & 188 & 1.111 & & & -0.860 & -0.821 & -0.803 & -0.845 & 0.621 & $(4,146)$ & $(1,146)$ \\
\hline$T$-value & & 3.630 & & & -5.710 & -5.450 & -5.340 & -5.570 & & 12.13 & 0.08 \\
\hline$P$-value & & 0.000 & & & $<0.0001$ & $<0.0001$ & $<0.0001$ & $<0.0001$ & & 0.00 & 0.78 \\
\hline Dividend to Sales & 265 & -0.015 & -0.010 & -0.001 & 0.046 & 0.060 & 0.034 & 0.036 & 0.488 & $(6,221)$ & $(1,221)$ \\
\hline$T$-value & & -0.61 & -0.72 & -0.1 & 3.33 & 4.33 & 2.45 & 2.55 & & 7.62 & 0.02 \\
\hline$P$-value & & 0.543 & 0.473 & 0.919 & 0.001 & $<0.0001$ & 0.015 & 0.011 & & 0.00 & 0.90 \\
\hline Payout Ratio & 265 & 0.063 & -0.094 & -0.055 & 0.049 & 0.236 & 0.159 & 0.104 & 0.256 & $(6,220)$ & $(1,220)$ \\
\hline$T$-value & & 0.49 & -1.27 & -0.74 & 0.67 & 3.2 & 2.15 & 1.39 & & 5.16 & 0.56 \\
\hline$P$-value & & 0.628 & 0.206 & 0.460 & 0.504 & 0.002 & 0.032 & 0.165 & & 0.00 & 0.45 \\
\hline
\end{tabular}


Note 1: In the analysis of ROS, $F$-test shows that the parameters of the event years -3 and -2 can be the same as those of the event year $-1 . F(2,221)=0.27, P$ value $=0.7613$.

Note 2 : In the analysis of SAL, $F$-test shows that the parameters of the event years -3 and -2 cannot be the same as those of the event year -1 at $5 \%$ significance level. $F(2,221)=3.70, P$-value $=0.0264$.

Note 3: In the analysis of AST, $F$-test shows that the parameters of the event years 1,2 , and 3 can be the same. $F(2,146)=0.01, P$-value $=0.9884$.

Note 4: In the analysis of LEV, $F$-test shows that the parameters of the event years 1,2 , and 3 can be the same. $F(2,146)=1.25, P$-value $=0.2885$.

Note 5: In analysis of LEV2, $F$-test shows that the parameters of event years 1,2 , and 3 can be the same at $5 \%$ significance level. $F(2,146)=0.04, P$-value $=0.9620$. Note 6: In the analysis of DIVSAL, $F$-test shows that the parameters of the event years -3 and -2 can be the same as those of the event year -1 . $F(2,221)=0.30, P$ value $=0.7397$. The parameters of the event years 1,2 , and 3 can be the same. $F(2,221)=2.19, P$-value $=0.1139$.

Note 7: In the analysis of PAYOUT, $F$-test shows that the parameters of the event years -3 and -2 can be the same as those of the event year $-1 . F(2,220)=0.81, P$ value $=0.4452$. The parameters of the event years 1,2 , and 3 can be the same. $F(2,220)=1.63, P$-value $=0.1986$. 


\section{Table 5 Is the Performance Change of the Newly Listed H-firms Different from That of the Control Firms?}

This table presents the Kruskal-Wallis tests of the hypothesis test that the performance change of the newly listed H-firms is the same as that of the control firms. The test of the hypothesis that the performance level difference between the H-firms and the control firms is the same before and after listing is also presented. The Kruskal-Wallis test is identical to the Mann-Whitney test when only two groups are compared. (H) represents the H-firms, and (C) the control firms. The table presents, for each accounting measure, the number of usable observations, the mean of the median for the three years before listing, the Kruskal-Wallis statistic and related $P$-value for testing the hypothesis that the performance level of the $\mathrm{H}$-firms and the control firms is the same, the mean of the median for the three years after listing, the Kruskal-Wallis statistic and related $P$-value for testing the hypothesis that the performance level of the $\mathrm{H}$ firms and the control firms is the same after listing, the median performance change on going public, and the Kruskal-Wallis statistic and related $P$-value for the hypothesis that the performance change of the $\mathrm{H}$-firms and the control firms on listing is the same. As we have not enough employee data on the control firms, we cannot examine the difference between the H-firms and the control firms with respect to EMPL, SALEFF, and NIEFF. 
Table 5: Is the Performance Change of Newly Listed H-firms Different from That of the Control Firms?

\begin{tabular}{|c|c|c|c|c|c|c|c|c|c|c|}
\hline Variables & $N$ & $\begin{array}{l}\text { Mean } \\
\text { Before }\end{array}$ & $\begin{array}{l}\text { Kruskal-Wallis } \\
\text { Statistic }\end{array}$ & $P$-value & $\begin{array}{l}\text { Mean } \\
\text { After }\end{array}$ & $\begin{array}{c}\text { Kruskal-Wallis } \\
\text { Statistic }\end{array}$ & $P$-value & $\begin{array}{l}\text { Median } \\
\text { Change }\end{array}$ & $\begin{array}{c}\text { Kruskal-Wallis } \\
\text { Statistic }\end{array}$ & $P$-value \\
\hline $\operatorname{ROS}(\mathrm{H})$ & 38 & 0.232 & 3.855 & 0.050 & 0.160 & 4.580 & 0.032 & -0.072 & 0.181 & 0.670 \\
\hline $\operatorname{ROS}(\mathrm{C})$ & 38 & 0.161 & & & 0.052 & & & -0.109 & & \\
\hline $\mathrm{ROA}(\mathrm{H})$ & 37 & 0.115 & 13.392 & 0.000 & 0.040 & 0.200 & 0.655 & -0.075 & 6.372 & 0.012 \\
\hline $\mathrm{ROA}(\mathrm{C})$ & 37 & 0.184 & & & 0.010 & & & -0.174 & & \\
\hline $\mathrm{ROE}(\mathrm{H})$ & 37 & 0.466 & 11.935 & 0.001 & 0.059 & 1.427 & 0.232 & -0.407 & 4.766 & 0.029 \\
\hline $\operatorname{ROE}(\mathrm{C})$ & 38 & 0.577 & & & 0.022 & & & -0.555 & & \\
\hline AST $(H)$ & 37 & 0.748 & 19.999 & $<0.0001$ & 0.458 & 24.044 & $<0.0001$ & -0.281 & 1.460 & 0.227 \\
\hline $\mathrm{AST}(\mathrm{C})$ & 38 & 1.670 & & & 1.166 & & & -0.504 & & \\
\hline $\operatorname{SAL}(\mathrm{H})$ & 38 & 0.821 & 7.073 & 0.008 & 1.066 & 0.005 & 0.942 & 0.245 & 1.713 & 0.191 \\
\hline SAL (C) & 38 & 0.664 & & & 1.271 & & & 0.607 & & \\
\hline $\operatorname{LEV}(\mathrm{H})$ & 37 & 0.656 & 0.033 & 0.857 & 0.412 & 3.614 & 0.057 & -0.237 & 1.101 & 0.294 \\
\hline LEV (C) & 38 & 0.667 & & & 0.514 & & & -0.153 & & \\
\hline LEV2 $(\mathrm{H})$ & 37 & 1.421 & 10.242 & 0.001 & 0.339 & 2.957 & 0.086 & -0.312 & 2.733 & 0.098 \\
\hline LEV2 (C) & 38 & 1.875 & & & 0.168 & & & -0.500 & & \\
\hline DIVSAL $(\mathrm{H})$ & 38 & 0.009 & 8.872 & 0.003 & 0.057 & 3.742 & 0.053 & 0.048 & 7.822 & 0.005 \\
\hline DIVSAL (C) & 38 & 0.035 & & & 0.029 & & & -0.005 & & \\
\hline PAYOUT $(\mathrm{H})$ & 37 & 0.133 & 6.324 & 0.012 & 0.357 & 7.314 & 0.007 & 0.228 & 9.240 & 0.002 \\
\hline PAYOUT (C) & 38 & 0.283 & & & 0.187 & & & -0.096 & & \\
\hline
\end{tabular}




\section{Figure 1 Descriptive Accounting Measures of H-Firms' Performance Change}

Panels 1-6 present performance proxies for the H-firms and the control firms before and after going public, one accounting measure in each panel. Panels 1, 5, and 6 show ROS, SAL, and PAYOUT for the seven-year period consisting of the three years prior and subsequent to going public as well as the year of going public(the base year). The other three proxies represent only five years' data, one year before and three years after going public plus the year of going public, because the relevant accounting data are not compulsory disclosure items in the H-firms' prospectuses and not many Hfirms publish these data. In the panels, $\mathrm{Y}-3, \mathrm{Y}-2, \mathrm{Y}-1, \mathrm{Y} 0, \mathrm{Y} 1, \mathrm{Y} 2$, and $\mathrm{Y} 3$ represent the event years, that is, the years relative to the going public year. Inflation-adjusted real sales in panel 5 are normalized to equal 1.000 in the event year 0 , so the other event year figures are expressed as a fraction of the base year figures. The data employed in these panels are the means for the $\mathrm{H}$-firms and the control firms. 

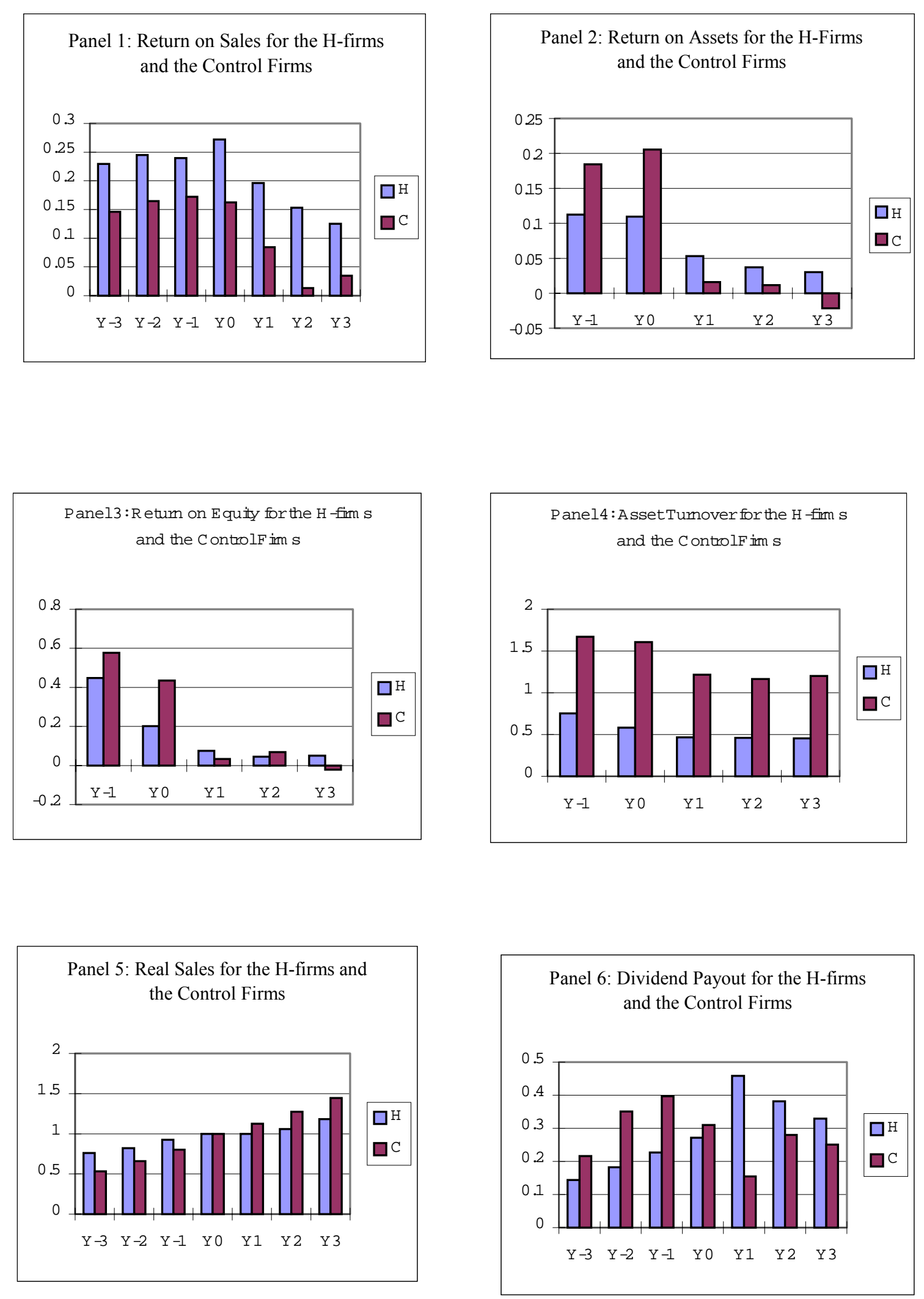